\title{
LIQUIDITY OF THE CROATIAN STOCK MARKET: AN EMPIRICAL ANALYSIS
}

\author{
Jelena Z. Minovic * \\ Keywords: Croatian Frontier Market, (Il)liquidity, Zero Rates Return , Price \\ Pressure (PP), Turnover (TO) \\ JEL: G10, 016
}

\begin{abstract}
In this paper we analysed liquidity of the Croatian stock market. Low level of liquidity is one of the key problem areas facing this small market. As the measures of liquidity we used the Zero Rates return by Lesmond et al. (1999), Price Pressure of non-trading as in Bekaert et al. (2007), and Turnover. For calculating the Zero Rates return, and Price Pressure measures we used prices of all stocks listed at the the Zagreb Stock Exchange in the period: 2005 - 2009. Results showed that the level of liquidity for the Croatian market is very low. For this market the least illiquid year was 2007 (the pre-crises year), and most illiquid year for Croatia was 2009. We showed that illiquidity is persistent in this market. The first measures of correlation between all illiquidity measure are given. Particularly, we demonstrated that the Croatian market is less illiquid than the Serbian market.
\end{abstract}

\footnotetext{
*Researcher, +381112624358, jelena.minovic@ien.bg.ac.rs, Institute of Economic Sciences, Zmaj Jovina 12, 11000 Belgrade
}

Jelena Z. Minovic - LIQUIDITY OF THE CROATIAN STOCK MARKET: 


\section{Introduction}

The financial market in Croatia is, by its type, a Frontier Market. Frontier markets describe the smallest, less developed, less liquid countries that make up emerging markets. The main problem of the frontier markets impacting market liquidity are: small number of stocks with significant capitalization, small numbers of shares outstanding, infrequent and irregular trading, etc. Additionally, there are typically short time series of past trades, lack of transparency and readily accessible information about traded companies, as well as the appearance of the so-called invisible forms of risk, where illiquidity is the most important one. Due to all these factors frontier markets suffer from the increased level of systematic (market) risk (Latković and Barac, 1999). In frontier markets, non-trading problems are particularly acute. The time period between two subsequent trades can be several weeks. Such a situation is certainly not common for traded securities in developed capital markets (Latković, 2001). Frontier markets have some specific features that cannot be found in developed markets (Latković and Barac, 1999). These markets are characterized by a relatively large number of illiquid stocks (Benić and Franić, 2008). Undeveloped market often features low liquidity and infrequent trading. Investors in these markets are attracted by the high return potential but, at the same time, are scared by the liquidity risk in the market (Zhang, 2010).

Hacibedel (2007) listed some of the major differences between emerging and developed markets: difference in the level of information efficiency (the cost of information, and asymmetry of information between domestic and foreign investors); difference with respect to the investor base; distinction between foreign and local investors in emerging markets, both in terms of risk taking behaviour and weight; difference in terms of level of homogeneity of the assets, i.e. 'within market segmentation'; difference is the stock liquidity, and difference in the level of integration with the world markets.

There are many available research papers on liquidity and its measuring. These papers are mainly focused on developed markets. There are no major research ventures on stock market liquidity and its measuring in the South Eastern Eu-

Jelena Z. Minovic - LIQUIDITY OF THE CROATIAN STOCK MARKET: AN EMPIRICAL ANALYSIS 
rope countries. This paper contributes to this field of research in terms of determining level of the Croatian market illiquidity and comparing it's with level of the Serbian market illiquidity.

Benić and Franić (2008) determined the level of liquidity on the Croatian stock market and on the developing markets that are part of Central and Eastern Europe. They compared the Croatian market liquidity with other markets in the region and then compared those results with the German market in order to perceive differences between developing and developed markets. Rouwenhorst (1999) analysed returns and liquidity in 20 emerging markets. Bekaert and Harvey $(2002,2003)$ analysed different emerging markets. Clark (2008) studied history and measurement of liquidity risk in frontier markets. Bekaert, Harvey, and Lundblad (2007) analysed measuring of liquidity for 19 emerging equity markets. Cajueiroa i Tabak (2004) analysed emerging markets, too. They showed that these markets tend to become more efficient in time. Lesmond (2005) studied and tested different liquidity measures for emerging markets. Yeyati, Schmukler, and Van Horen (2008) described behaviour of emerging market liquidity in crises period. Hearn, Piesse, and Strange (2009) analysed liquidity in African emerging markets. Živkoviæ and Minoviæ (2010) explored illiquidity of the Serbian stock market.

There are many risks associated with investing in frontier markets. Živković and Minovic (2010) showed that market illiquidity and its volatility significantly varies over time on the Serbian market. In these smaller frontier markets unpredictability of liquidity is also important source of risk. The simple fact is that for periods of time, there may be no market for a stock in a frontier market company. The regulatory scheme within these countries varies and often provides far less oversight than in more developed countries .

Liquidity is a market characterized by the ability to buy and sell securities with relative ease. Another definition that could be used in frontier markets explains that illiquidity arises when an asset or security cannot be converted to cash quickly, thus defining liquidity as the opposite of same (Clark, 2008). Liquidity on stock exchange is generated by the so called market makers (Campbell, Lo, and MacKinlay, 1997). Speculative investors and market makers are the 
key players that bring about market or assets liquidity (Huberman and Halka, 2001). Liquidity is one the favourable characteristics required by the investors. Indeed, liquidity is the condition for investors (regardless of the investors being individuals or institutions) to get returns from the expected changes in prices. They, however, generate demand which enables liquidity.

To measure illiquidity for the Croatian market we use zero-return (ZR) proportion (by Lesmond, Ogden, and Trzcinka, 1999), "price pressure" (PP) measure as in Bekaert, Harvey, and Lundblad (2007), and turnover. Many of the more sophisticated measures of liquidity are unusable for estimation of liquidity of the Croatian stock market, because of the lack of data and specific features of this market. We used daily data for stocks from the Croatian Stock Exchange Index - CROBEX (http://zse.hr/), as well as data for all stocks listed at the Zagreb Stock Exchange in the period: October 14, 2005 - December 31, 2009. In order to obtain and apply the corresponding illiquidity measures, we have written a computer program within Microsoft Access package. We analysed level of liquidity for the whole Croatian market, and for CROBEX index, as well as for liquid and illiquid portfolio in the pre-crises and post-crises period. Particularly, we found which year is the most illiquid and the least illiquid year in observed sample period. Additionally, we compared Croatian and Serbian markets illiquidity by ZR measure.

The rest of the paper is organized as follows. The Section 2 describes liquidity, its definition and dimensions. The Section 3 presents different liquidity measures used in empirical analysis of Croatian market, and their advantages and disadvantages. The Section 4 shows changes in the level of illiquidity for each year in observed sample period, as well as the level of illiquidity in the pre- and post-crises eras, for CROBEX index, and for liquid and illiquid portfolio. The Section 5 concludes.

\section{Liquidity: definition and dimensions}

Liquidity is not easy to define and there is no common definition of liquidity anyway (Wyss, 2004). Liquidity is easier to recognize than to define (Crockett, 
2008). Liquidity generally denotes the ability to trade large quantities quickly, at a low cost, and without moving the price. Market liquidity refers to the ability to undertake transactions in such a way as to adjust portfolios and risk profiles without disturbing underlying prices. The dimensions of market liquidity include:

1. (a) market depth, or the ability to execute large transactions without influencing prices unduly (Crockett, 2008). Market depth can be measured, aside from the depth itself, by the order ratio, the trading volume or the flow ratio (Wyss, 2004);

(b) tightness, or the gap between bid and offer prices (Crockett, 2008). Tightness shows in the clearest way the cost associated with transacting or the cost of immediacy. Measures for tightness are the different versions of the spread (Wyss, 2004);

(c) immediacy or the speed with which transactions can be executed (Crockett, 2008);

(d) resilience, or the speed with which underlying prices are restored after a disturbance (Crockett, 2008). The resiliency dimension takes the elasticity of supply and demand into account (Wyss, 2004);

(e) trading time is the ability to execute a transaction immediately at the prevailing price. The waiting time between subsequent trades or the inverse, the number of trades per time unit are measures for trading time (Wyss, 2004).

Obviously, there is a strong interaction between each of these dimensions and all of them must be monitored since the quality and availability of data varies widely across markets. These dimensions need to be applied at a disaggregated level for segmented markets and for individual products where substitutability from an investor's standpoint is limited or absent (Fernandez, 1999). It was believed that market liquidity could be analysed in terms of objective exogenous factors. A market was thought likely to be liquid if:

1. (a) market infrastructure was efficient, leading to low transactions costs and thus narrow bid-ask spreads;

Jelena Z. Minovic - LIQUIDITY OF THE CROATIAN STOCK MARKET: AN EMPIRICAL ANALYSIS 
(b) there was a large number of buyers and sellers, implying that order imbalances could be quickly adjusted by small movements in prices;

(c) and the assets transacted had transparent characteristics, so that changes in perceptions of underlying value would be quickly translated into prices (Crockett, 2008).

Amihud, Mendelson, and Pedersen (2005) noted some of the main factors that affect the liquidity of assets:

1. (a) Exogenous transaction costs: these are costs incurred by the buyer and/or seller of a security each time it is traded, including brokerage fees, order processing costs and transaction taxes.

(b) Inventory risk: sellers also incur costs when they are forced to sell to market makers because „natural? buyers of the security are not present in the market at the time of sale; the market maker holds the security in inventory until such time as buyers appear but needs to be compensated for the risk of performing this role.

(c) Private information: in a situation where either the buyer has private information that an investment is likely to appreciate in value or the seller has private information about anticipated asset write downs, a trading loss will arise for the uninformed counterparty. Dealers must adjust their quoted spreads to protect (on average) against losses incurred on trades with these ,informed? counterparties.

(d) Search friction: when an investor experiences difficulties in finding a counterparty who is willing to execute a trade this may result in him making price concessions he would not make in a perfectly competitive environment where buyers and sellers were immediately available; agents thus face opportunity costs between immediate execution of the deal at a discount and searching for a more attractive deal (Hibbert, Kirchner, Kretzschmar, Li, and McNeil, 2009).

Liquidity risk is considered to be one of the indirect barriers that foreign investors face while investing in emerging markets. The level of liquidity is 
much higher in developed markets than in emerging markets (Hacibedel, 2007). Chuhan (1994) notes the small size of the frontier markets and their poor liquidity as the main factors impeding interest in frontier markets. Živković and Minovic (2010) showed that in most cases the cause of the dramatic falls and rises in market illiquidity and of increases in the liquidity risk is the growth and fall in the foreign investor's participation. Penev and Rojec (2004) find that the main obstacles to foreign direct investment flows into the South-East Europe region are high investment risks, the lack of adequate physical infrastructure, delays in bank restructuring and rehabilitation, underdeveloped financial markets, delays in large-scale privatization and enterprise reform, inadequate development level of institutional infrastructure, administrative barriers to foreign direct investment, and an unfavourable legal environment. Benić and Franić (2008) pointed that a higher level of illiquidity directly leads to a higher risk on investments where investors face the possibility of higher losses, but also higher gains, when compared to more developed and liquid markets due to price volatility. In more illiquid markets (frontier markets) investors cannot be certain they would be able to execute large volume transactions at any time without significant price change, thus resulting in higher losses. Therefore, the presence of illiquidity represents an obstacle to further stock market development due to lower inflows of capital, which confirms that market liquidity is a fundamental aspect of market development.

Liquidity has several aspects and cannot be described by one indicator only. Some of the most common measures (il)liquidity are as follows: Turnover, BidAsk Spread, Roll's model (1984), Kyle's measure (1985), LOT's model (named by Lesmond, Ogden, and Trzcinka, 1999), Amihud's measure (2002), PástorStambaugh factor (2003), and others. Thus, it is very difficult to cover liquidity with only one variable. Liquidity can be well described as a function of a number of variables, where each variable is an approximation for incomprehensible concept of liquidity (Amihud, 2002). So far evolution of ideas in this field shows that measuring market liquidity is not a trivial issue. Lesmond (2005) concludes that any measuring of liquidity has its advantages and disadvantages when used for estimation of liquidity among countries or within some country. 
Lesmond (2005) points out that it is very important to choose appropriate measure of liquidity because these measures are necessary for adequate estimation of the market efficiency. However, the important issue for our analysis in this paper is the choice of appropriate measures of liquidity for frontier capital markets. Many of the more sophisticated measures of (il)liquidity could not be used for estimation of liquidity of the Croatian stock market, because of the lack of data and specific features of this market.

\section{Choosen Illiquidity Measures for the Croatian market}

\subsection{The Zero - Return Measure (The LOT's measure)}

Lesmond, Ogden, and Trzcinka (1999) proposed an illiquidity measure based on the portion of zero return days out of possible trading days. The zero-return measure is the ratio of the number of zero-return days to the total number of trading days in a given month (Lee, 2006). LOT's measure is defined as follows:

$$
Z R_{i, t} \equiv \frac{N_{i, t}}{T_{t}}
$$

where $T_{t}$ is a number of trading days in month $t$, and $N_{i, t}$ is the number of zero-return days of stock $i$ in month $t$.

The economic intuition for the zero return measure is derived from simple trade-offs of the cost and benefit of trading for informed investors: when the trading cost is too high to cover the benefit from informed trading, informed investors would choose not to trade and this non-trading would lead to an observed zero return for that day. Importantly, the zero-return measure is defined over zero-volume days as well as positive volume days since this measure assumes that a zero-return day with positive volume is a day when noise trading induces trading volume (Lee, 2006).

Lesmond (2005), and Bekaert, Harvey, and Lundblad (2007) found that each countries liquidity is best measured by LOT's model. Practical drawback

Jelena Z. Minovic - LIQUIDITY OF THE CROATIAN STOCK MARKET: 
of LOT's measure that it requires long enough period (i.e. longer than one month) in order to estimate parameters. Moreover a lot of zero-returns (i.e. if there are more than $80 \%$ for estimation period) make this measure invaluable. Bekaert et al. (2007) employed LOT's measure and they indicated that only this measure is applicable as illiquidity measure for emerging markets.

\subsection{The Price Pressure Measure}

Bekaert, Harvey, and Lundblad (2007) used this illiquidity measure for emerging markets, and it turned reliable in estimation of illiquidity of these markets. This measure aims to incorporate potential price impact by using the length of the non-trading (or zero return) interval. Bekaert et al. (2007) called this measure as price pressure of non-trading.

Daily price pressure (PP) measure is defined as follows:

$$
\mathrm{PP}_{i, t}=\frac{\sum_{j=1}^{N} \omega_{j} \delta_{j, t}\left|R_{j, t, \tau}\right|}{\sum_{j=1}^{N} \omega_{j}\left|R_{j, t, \tau}\right|}
$$

where $\omega_{j}$ represents the weighting of the stocks in the market index (Bekaert et al., 2007). In our case, the market index is CROBEX index. $N$ is number of stocks, each indexed by $j$. Coefficient $\delta_{j, t}$ indicates no trade days (as proxied by zero return days) and the first day after a no trade interval when the price impact is felt.

$$
\delta_{j, t}=\left\{\begin{array}{lll}
1, & \text { if } & R_{j, t} \text { or } R_{j, t-1}=0 \\
0, & \text { otherwise }
\end{array} .\right.
$$

Also,

$$
R_{j, t, \tau}=\left\{\begin{array}{ccc}
R_{j, t} & \text { if } & R_{j, t-1} \neq 0 \\
\prod_{k=0}^{\tau-1}\left(1+R_{m, t-k}\right)-1, & \text { if } & R_{j, t-1}=0
\end{array} .\right.
$$

Here $\tau$ represents the number of days the stock has not been trading and $R_{j, t, \tau}$ is an estimate of the return that would have occurred if the stock had traded. Because in frontier and emerging markets market-wide factors may dominate return behaviour with respect to idiosyncratic factors, we use the value-weighted market return, $R_{m, t}$, as our proxy for the unobserved return. Note that when

Jelena Z. Minovic - LIQUIDITY OF THE CROATIAN STOCK MARKET: 
a stock does not trade for a lengthy interval, $R_{j, t, \tau}$ may become quite large and the price impact illiquidity measure $\left(P P_{t}\right)$ may move to 1.0 (Bekaert et al., 2007).

Bekaert et al. (2007) specified the limitations of this measure. First, information less trades (such as a trade by an index fund) should not give rise to price changes in liquid markets. The fact that there is no actual measure for non-trading, but only a zero return, creates a potentially serious limitation. The market reaction to such a trade may also depend on the particular trading mechanism in place. Another concern is that there is no trading because of a lack of news. Also, it is possible that our price pressure measure artificially reflect other characteristics of the stock market. For example, markets with many small stocks may automatically show a higher level of non-trading compared to markets with larger stocks. The focus on a value-weighted measure mitigates this concern (Bekaert et al., 2007).

\subsection{Turnover}

Turnover (TO) is:

$$
\mathrm{TO}_{i y}=\frac{1}{N_{i y}} \sum_{t=1}^{N_{i y}} \frac{V_{i y t}}{n_{i y t}} .
$$

Where $V_{\text {iyt }}$ is trade volume in shares of stock $i$ on day $t$ in year $y$, and $n_{\text {iyt }}$ is number of shares outstanding of stock $i$ on that day (Amihud, 2002).

Benić and Franić (2008) used Amihud's (2002) illiquidity measure in order to compare the most liquid stocks of the Croatian, Bulgarian, Serbian, Hungarian, Slovenian, Polish, and German markets. These authors showed that the Croatian market is more liquid than Bulgarian and the Serbian market, significantly more illiquid than Hungarian, Polish and German market and at a similar level of liquidity as the Slovenian market.

The characteristics of emerging markets could lead to liquidity being measured with more noise, if the existing liquidity proxies proposed based on the US market are used. Compared to the US market, emerging markets have more insider trading and weaker corporate governance. Investors, especially retail in-

Jelena Z. Minovic - LIQUIDITY OF THE CROATIAN STOCK MARKET: AN EMPIRICAL ANALYSIS 
vestors, have the expectation that they can be expropriated by the management or more informed investors. They also have relatively low disposable income to invest in the stock market and limited resource to obtain information. All these factors result in the on average low trading activity in the emerging markets. In other words, trading frequency becomes particularly important in emerging markets but the existing liquidity proxies rarely consider it. On the other hand, trading activeness vary across individual markets (Zhang, 2010).

Models based on the volume such as Amihud's measure and Turnover could be misleading in case of weak liquidity markets. This shortage is practically manifested in reduced scope of revenue which affects turnover, as well as null returns which influence Amihud's measuring (Lesmond, 2005). Findings by Lesmond (2005), Bekaert, Harvey, and Lundblad (2007) show that turnover are not a sustainable measure of liquidity in emerging markets. Neither is it a good measure for estimation of liquidity among countries nor within each country (Lesmond, 2005), (Bekaert et al., 2007).

\section{Empirical Results}

\subsection{Data}

The Zagreb Stock Exchange (ZSE) operations were suspended in 1945. Croatia's exchange did not see its revival until as late as 1991. In 1994, an electronic trading system was introduced. In the first five years following the introduction of the electronic trading system, between 1995 and 2000, the Zagreb Stock Exchange market capitalization grew almost 10 times. $^{1}$

We used relatively short time-series (length of 4.5 years), from October, 2005 to December, 2009, compared with similar researches conducted on developed markets, where available time-series are above 20 years long. Another problem is that global economic crises happened during covered estimation period.

\footnotetext{
${ }^{1}$ http://zse.hr/default.aspx?id=32877 (accessed July 29, 2011).
}

Jelena Z. Minovic - LIQUIDITY OF THE CROATIAN STOCK MARKET: 
We have daily data ${ }^{2}$ for all stocks ${ }^{3}$ listed at the Zagreb Stock Exchange for the period: 2005-2009. Daily returns are calculated as difference in log price at closing, as follows:

$$
R_{t}^{i}=\log \left(P_{t}^{i}\right)-\log \left(P_{t-1}^{i}\right)=\log \left(\frac{P_{t}^{i}}{P_{t-1}^{i}}\right) .
$$

where $\log \left(P_{t}\right)$ is $\log$ value of stock price on day $\mathrm{t}$, and $\log \left(P_{t-1}\right)$ is $\log$ value of stock price on day $\mathrm{t}-1$.

We got data for Croatian Stock Exchange Index (CROBEX) and for its structure for period: 2005-2009, from the Zagreb Stock Exchange (http://zse.hr/). The value-weighted return of this index is calculated using equation (6). After calculating returns for each stocks and index, we calculated liquidity measures for each stocks in each particular month of the observed period.

In order to obtain level of illiquidity for whole the Croatian market, we used Zero Rates (ZR) return by Lesmond, Ogden, and Trzcinka (1999) as a measure of stock illiquidity. In order to obtain and apply the corresponding illiquidity measure, we have written a program within Microsoft Access package. ZR is calculated for each stock in each particular month. After calculating return and illiquidity series on a daily level, we have been averaged by months in order to obtain series on a monthly level. Then, we sorted all stocks in each particular month according to value of $\mathrm{ZR}$ in ascending order, using the same program. For further analysis we rejected stocks that had zero returns in over $80 \%$ cases, in each month. ${ }^{4}$ The stocks would be grouped in two portfolios. This would be two equally-weighted portfolios consisted of the 20 most liquid and the 20 least liquid stocks. These two portfolios are rebalanced monthly. Daily log returns for CROBEX index, and for both portfolios are presented on Figure 1.

\footnotetext{
${ }^{2}$ Prices got on request from firm QuoteStation, http://www.quotestation.com/ (accessed January 25, 2010).

${ }^{3}$ In the period: 2005-2009 at the Zagreb Stock Exchange listed about 350 stocks.

${ }^{4} \mathrm{~A}$ lot of zero-returns (i.e. if there are more than $80 \%$ for estimation period) make this measure invaluable.
}

Jelena Z. Minovic - LIQUIDITY OF THE CROATIAN STOCK MARKET: AN EMPIRICAL ANALYSIS 

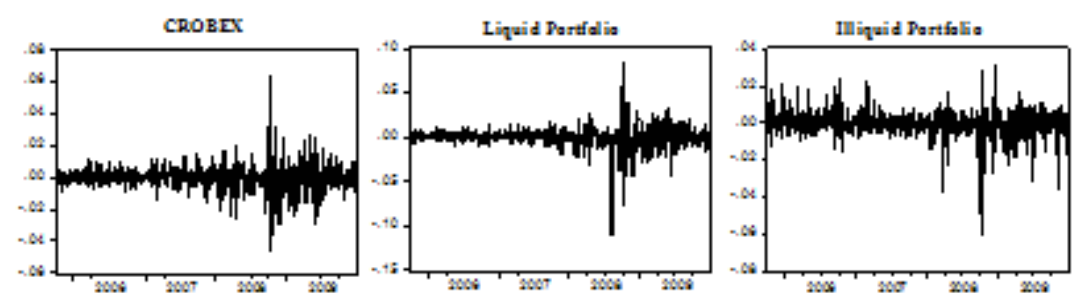

Source: Author calculation

FIGURE 1- Daily log returns for CROBEX index, liquid, and illiquid portfolio for period: 2005-2009.

For calculating the level of illiquidity for CROBEX index, and for two portfolios liquid and illiquid, on a daily level, we used price pressure (PP) of non-trading as in Bekaert, Harvey, and Lundblad (2007). This measure is calculated using a program that we have written within Microsoft Access package. We have daily turnover of all stocks listed at the Zagreb Stock Exchange in observed period. We calculated daily turnover for CROBEX index and for two portfolios in the pre-crises and post-crises periods. In Appendix in Table A1 there are descriptive statistics of returns, PP measures, and turnover for CROBEX index, liquid and illiquid portfolio, respectively.

\subsection{Liquidity behaviour on the Croatian market}

Many of the more sophisticated liquidity measures which are applicable for developed markets require the use of high-frequency transactions and quotes data, which may not be available for some markets, especially emerging and frontier markets (Zhang, 2010). These sophisticated measures of liquidity could not be used for estimation of liquidity of the Croatian stock market, because of the lack of the data and specific features of this market. In case of Croatian market, illiquidity is measured using three measures, Zero Rates (ZR) return, Price Pressure of non-trading (PP), and Turnover (TO). The Zero Rates, and Price Pressure of non-trading measures are used in Bekaert, Harvey, and Lundblad (2007). These authors applied this two illiquidity measures for 19 emerging 
markets, and it turned out reliable in estimation of illiquidity of these markets. For the construction of these two measures only data on stock prices and index at closing were sufficient. Selected measures of illiquidity, ZR and PP, have values ??in the range between 0 and 1 . If the value of these measures is closer to 1 , this means that illiquidity is extremely high. For calculating ZR measure we used equation (1). This measure can be obtained for every stock on a monthly basis. Then, its value is averaged for all the stocks and the whole of the observed period.

Bekaert, Harvey, and Lundblad (2007) found that the least liquid country is Colombia according to the value of $\mathrm{ZR}$ measure (average value of $\mathrm{ZR}=$ 0.773 ). The country with average value of $\mathrm{ZR}=0.109$ is Taiwan (Bekaert et al., 2007), interpreting that Taiwan is the most liquid country of all 19 analyzed emerging markets. In order to find level of markets' liquidity in Croatia, we have established some critical value. An average value of ZR for all 19 analyzed emerging markets in Bekaert, Harvey, and Lundblad (2007) was 0.495.

We decided to denote all average values of ZR measure above 0.495 as state of low liquidity. For whole the Croatian market, value of ZR measure in the case when excluded stocks have more than $80 \%$ of zero returns, is 0.361 (Table 1), indicating that the Croatian market is liquid. However, from Table 1 we can see that mean value of $\mathrm{ZR}$ measure in the case when excluded stocks have more than $99 \%$ of zero returns, is 0.524 . This would be the most realistic representative of the level of illiquidity. As the number of 0.524 is higher than the critical value of 0.495 , we can say that the Croatian market is low liquid (illiquid).

TABLE 1- The mean of ZR measure for whole the Croatian market and for the whole observed period.

\begin{tabular}{lccc}
\hline \hline & to $80 \%$ & to $90 \%$ & to $99 \%$ \\
\hline $\begin{array}{l}\text { ZR measure } \\
\text { whole market }\end{array}$ & 0.361 & 0.438 & 0.524 \\
\hline \hline
\end{tabular}

Source: Author's calculation

Jelena Z. Minovic - LIQUIDITY OF THE CROATIAN STOCK MARKET: AN EMPIRICAL ANALYSIS 
Notes: The mean of $Z R$ measure in cases when excluded stocks have more than $80 \%, 90 \%$, and $99 \%$ of zero returns, respectively.

According to the data in Table 2, for every year, value of ZR measure was above the critical value of 0.495 , except in 2007, indicating that in the Croatian market, illiquidity is persistent. Indeed, persistence of liquidity are empirically proved by the following authors: Amihud (2002), Chordia, Roll, and Subrahmanyam (2000, 2001), Hasbrouck and Seppi (2001), Huberman and Halka (2001), Pástor and Stambaugh (2003), Acharya and Pedersen (2005), and others. Živković and Minović (2010) empirically demonstrated persistence of illiquidity and its volatility on the Serbian market. Croatian market was the most illiquid in 2009, while it was the least illiquid in 2007. This is an interesting result, since in the pre-crises period, market has reached "the peak" in the sense that it was the least illiquid. Then the market suffered a fall almost by Gaussian law, in the sense that it has reached maximum illiquidity.

TABLE 2- An average value of ZR measure for every year in observed period for whole market.

\begin{tabular}{lccccc}
\hline \hline & 2005 & 2006 & 2007 & 2008 & 2009 \\
\hline $\begin{array}{l}\text { ZR measure - whole market } \\
\text { to } 99 \%\end{array}$ & 0.540 & 0.519 & 0.494 & 0.519 & 0.572 \\
\hline \hline
\end{tabular}

Source: Authors' calculation

Notes: The mean of ZR measure in case when excluded stocks having more than 99\% of zero returns.

We calculated ZR measure for the Serbian market in order to compare market illiquidity in Croatia and Serbia. From Figure 2 we can see that average value of ZR measure for the Serbian market in the case when excluded stocks having more than $99 \%$ of zero returns, is significantly higher than average value of ZR for the Croatian market. Thus, the Croatian market is less illiquid than the Serbian market. 


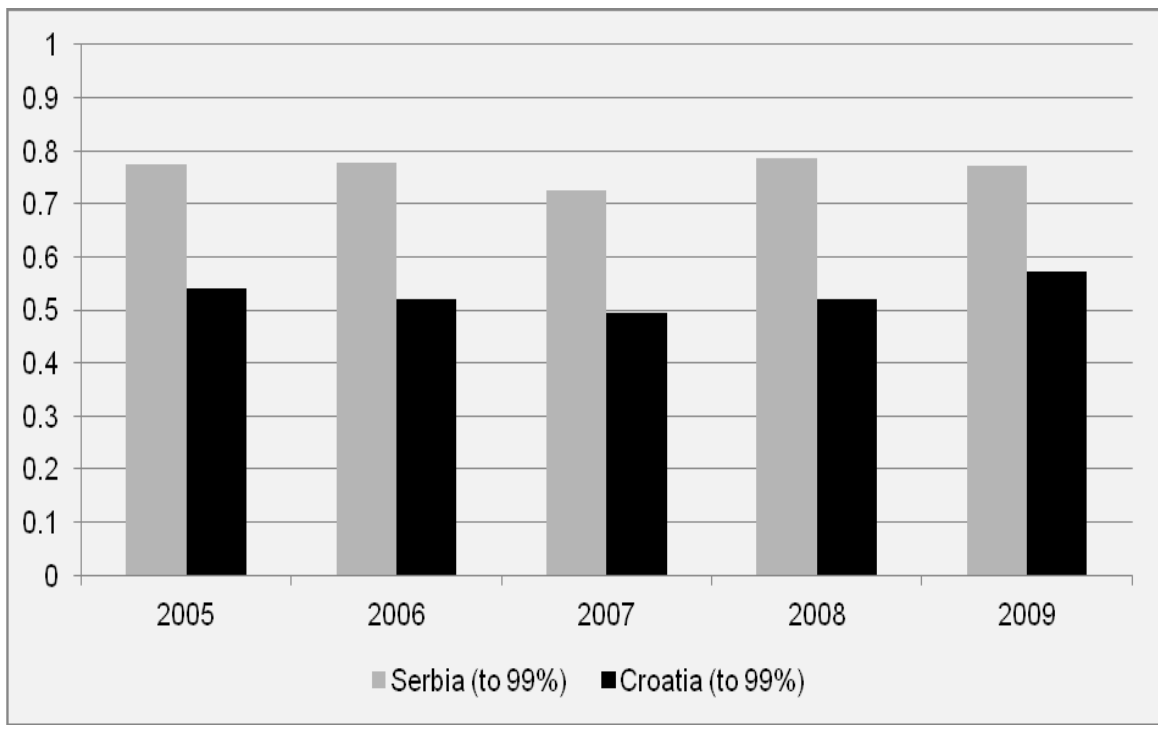

FIGURE 2- An average values of ZR measures for whole the Croatian and Serbian market, for every year in observed period, in case when excluded stocks having more than $99 \%$ of zero returns.

Source: Authors calculation

We sorted all stocks in each particular month according to value of ZR in an ascending order, using the program. For further analysis we rejected stocks that had zero returns in over $80 \%$ cases, in each month. The stocks were grouped in two portfolios. These were two equally-weighted portfolios consisted out of the 20 most liquid and the 20 least liquid stocks. These two portfolios are rebalanced monthly. For calculating price pressure (PP) measure as in Bekaert, Harvey, and Lundblad (2007), we used equation (2). This measure is obtained for CROBEX index and for two portfolios liquid and illiquid, on a daily level. PP measure is calculated using a program written in Microsoft Access package. Figure 3 presents equally-weighted PP measures for both portfolios and for CROBEX index. These PP measures are averaged for each month of observed period: 2005-2009. From Figure 3 we can observe that the level of illiquidity

Jelena Z. Minovic - LIQUIDITY OF THE CROATIAN STOCK MARKET: 
(measured by PP) is very unstable for both portfolios, and for index. The value of PP for CROBEX index is closer to the value of PP for liquid portfolio than the value of $\mathrm{PP}$ for illiquid portfolio (average values of $\mathrm{PP}$ measures are given in Table 3). Bekaert, Harvey, and Lundblad (2007) found that Indonesia is the least liquid country according to the value of $\mathrm{PP}$ measure (mean of $\mathrm{PP}=0.776$ ). Taiwan has a mean of PP measure $=0.158$, implying that Taiwan is the most liquid country of all 19 analyzed emerging markets. PP's average value for all 19 analyzed emerging markets was 0.552 in Bekaert, Harvey, and Lundblad (2007). We have then decided to denote all values of PP measure above 0.552 as low liquidity. From Table 3 we can see that average value of $\mathrm{PP}$ for illiquid portfolio is 0.820 that is higher than critical value of 0.552 . Opposite, average value of PP for liquid portfolio is 0.012 that is significantly lower than critical value of 0.552 . Živković and Minović (2010) showed that the mean of illiquidity measure PP is 0.605 for Serbia's BELEXline index, for the same period: 2005-2009. These authors interpreted this result that the Serbian market is illiquid. This PP average value is significantly higher than average value of PP for CROBEX index 0.067. We can say that BELEXline index is more illiquid than CROBEX index. Even that the Serbian market is more illiquid than the Croatian market. On these two markets there are big differences in features of stocks. Consequently, there is big difference in structure and constructing market index. 


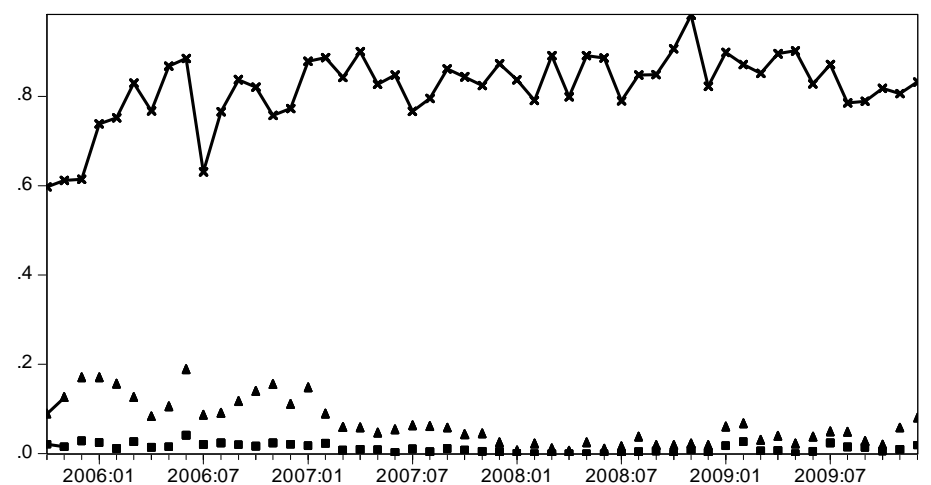

FIGURE 3- The equally-weighted Illiquidity measures (PP) for CROBEX index, liquid and illiquid portfolio, on monthly basis, for period: 2005-2009.

Source: Authors calculation

We calculated daily turnover for CROBEX index, and for two portfolios in the pre-crises and post-crises periods (see Table 3 ). In Table 3 we presented relative changes in turnover of CROBEX index and for two portfolios liquid and illiquid in the crises period (October, 2008).

From Figure 4 we can observe that a large turnover existed on the Zagreb Stock Exchange in the pre-crises period. In the post-crises period turnover significantly decreased. Turnover of CROBEX index decreased for $36 \%$, turnover of 20 the most liquid stocks decreased for $31 \%$, while turnover of the 20 illiquid stocks decreased over $68 \%$ (see Table 3). Consequently, when turnover (trading activity) decreased, illiquidity increased in the market. 

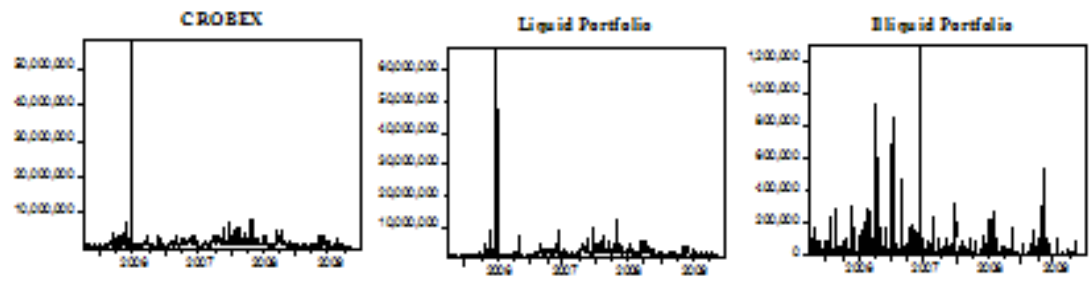

FIGURE 4- Daily turnover in KN for CROBEX index, liquid, and illiquid portfolio for period: 2005-2009.

Source: Authors calculation

TABLE 3- Average values of PP, ZR measures, and daily turnover for CROBEX index, liquid and illiquid portfolio.

\begin{tabular}{lcccccc}
\hline \hline & $\begin{array}{c}\text { Average } \\
\mathrm{PP}\end{array}$ & $\begin{array}{c}\text { Average } \\
\mathrm{ZR}\end{array}$ & $\begin{array}{l}\text { Average } \\
\mathrm{TO}(\mathrm{kn})\end{array}$ & $\begin{array}{c}\mathrm{TO}(\mathrm{kn}) \text { to } \\
30 / 09 / 08\end{array}$ & $\begin{array}{c}\mathrm{TO}(\mathrm{kn}) \\
\text { from } \\
01 / 10 / 08\end{array}$ & $\begin{array}{c}\text { Relative } \\
\text { changes } \\
\text { TO }\end{array}$ \\
\hline $\begin{array}{l}\text { CROBE } \\
\mathrm{X}\end{array}$ & 0.067 & 0.107 & $1,397.47$ & $1,562.48$ & $1,001.65$ & $-35.9 \%$ \\
$\begin{array}{l}\text { Liquid } \\
\text { portfolio }\end{array}$ & 0.012 & 0.027 & $1,522.55$ & $1,676.05$ & $1,154.35$ & $-31.1 \%$ \\
$\begin{array}{l}\text { Illiquid } \\
\text { portfolio }\end{array}$ & 0.820 & 0.746 & 33,927 & 42,471 & 13,432 & $-68.4 \%$ \\
\hline \hline
\end{tabular}

Source: Author's calculation

Notes: Average value of daily turnover in KN for CROBEX index, liquid and illiquid portfolio is given, in the pre-crises and the post-crises period, as well as relative changes of $T O$ in the crises period.

The correlation coefficients between two illiquidity measures ZR and PP are pretty high, 0.96, 0.84 and 0.62, for CROBEX index, liquid and illiquid portfolio, respectively (see Tables 4 and 5). The correlation coefficient between turnover and ZR measure for CROBEX index is -0.30 , and it is statistically significant (see Table 4), while for liquid portfolio the correlation coefficient is -0.40 , and it is statistically significant (see Table 5). Negative values of these correlation coefficients between level of illiquidity and turnover (or trading activities) means

Jelena Z. Minovic - LIQUIDITY OF THE CROATIAN STOCK MARKET: 
that high level of illiquidity (big values of ZR or PP), leads to smaller trading activities, or smaller turnover.

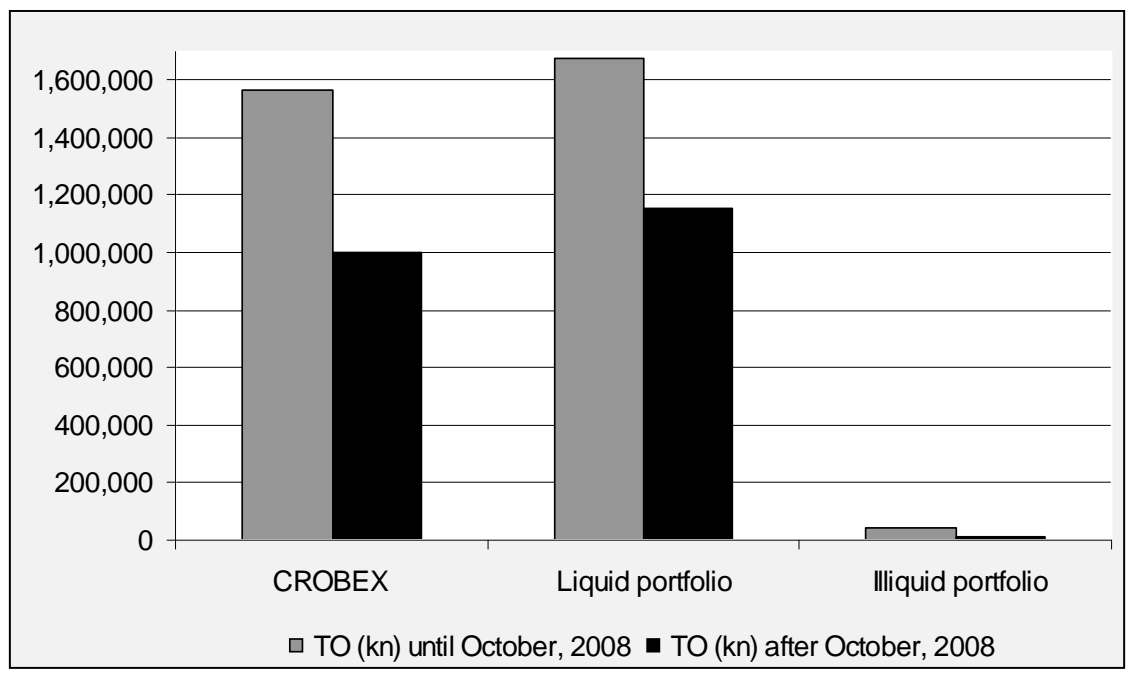

FIGURE 5- Daily turnover in KN for CROBEX index, liquid, and illiquid portfolio before and after October, 2008.

Source: Authors calculation

TABLE 4- The correlation matrix between different liquidity measures for CROBEX index.

\begin{tabular}{lccc}
\hline \hline & ZR & PP & TO \\
\hline ZR & 1.00 & & \\
PP & 0.96 & 1.00 & \\
& {$[23.03]$} & & \\
& $(0.00)$ & & 1.00 \\
TO & -0.30 & -0.18 & \\
& {$[-2.12]$} & {$[-1.27]$} & \\
& $(0.04)$ & $(0.21)$ & \\
\hline \hline
\end{tabular}

Source: Author's calculation.

Jelena Z. Minovic - LIQUIDITY OF THE CROATIAN STOCK MARKET: 
Notes: The values of t-statistics are given in angle parenthesis, and p-values are in standard parenthesis. The first measure of correlation is presented between Zero Rates Return (ZR), price pressure of non-trading (PP) and Turnover (TO). For illiquid portfolio there is no statistically significant correlation coefficient between any illiquidity measure (ZR or PP) and turnover (Table 5). It means that on the Croatian market, for the observed period, mainly liquid stocks are traded (see Figure 5). The big impact on market liquidity, in different times, had stocks of the following companies: INA, Croatian Telekom, Adris grupa, Atlantska plovidba, Ericsson-Nikola Tesla, and Podravka. These liquid stocks have impact on turnover and on the level of market liquidity.

TABLE 5- The correlation matrix between different liquidity measures for liquid and illiquid portfolio.

\begin{tabular}{lccc}
\hline \hline & ZR & PP & TO \\
\hline Liquid portfolio & & & \\
ZR & 1.00 & & \\
PP & 0.84 & 1.00 & 1.00 \\
& {$[10.90]$} & & \\
TO & $(0.00)$ & & \\
& -0.40 & -0.28 & \\
& {$[-3.01]$} & {$[-2.01]$} & \\
Illiquid portfolio & $(0.00)$ & $(0.05)$ & \\
ZR & & & \\
PP & 1.00 & & \\
& 0.62 & 1.00 & \\
& {$[5.55]$} & & \\
TO & $(0.00)$ & & \\
& -0.09 & -0.07 & \\
& {$[-0.60]$} & {$[-0.51]$} & \\
\hline \hline
\end{tabular}

Source: Author's calculation.

Notes: The values of t-statistics are given in angle parenthesis, and p-values are in standard parenthesis. The first measure of correlation is presented between

Jelena Z. Minovic - LIQUIDITY OF THE CROATIAN STOCK MARKET: 
Zero Rates Return (ZR), price pressure of non-trading (PP) and Turnover (TO).

\section{CONCLUSION}

This paper presents empirical analysis of liquidity for the Croatian stock market. For this analysis we used three measures: Zero Rates (ZR) returns, Price Pressure (PP) of non-trading as in Bekaert, Harvey, and Lundblad (2007), and turnover (TO). We used daily data for stocks from CROBEX index, as well as data for all stocks listed at the Zagreb Stock Exchange in the period: October, 2005 - December, 2009. In order to obtain and apply the corresponding illiquidity measures (ZR and PP), we have written a computer program in Microsoft Access package. Results showed that the level of liquidity for the Croatian market is very low. For this market the least illiquid year was 2007 (the pre-crises year), and most illiquid year for Croatia was 2009. The first measures of correlation between all illiquidity measure are given. We found that for illiquid portfolio there is no statistically significant correlation coefficient between any illiquidity measure (ZR or PP) and turnover. It means that on the Croatian market mainly liquid stocks are traded. The big impact on market liquidity, in different times, had stocks of the following companies: INA, Croatian Telekom, Adris grupa, Atlantska plovidba, Ericsson-Nikola Tesla, and Podravka. These liquid stocks have impact on turnover and on the level of market liquidity. Our results demonstrated that in the crises period turnover of liquid stocks decreased for $31 \%$. On the illiquid segment of the Croatian market stocks turnover decreased over $68 \%$ in the crises period. Consequently, illiquidity of both segment, liquid and illiquid, of the Croatian market increased in the post-crises period. The presence of illiquidity is one of the key barriers that foreign investors face while investing in frontier markets. It represents main barrier to further stock market development due to lower inflows of capital. Market liquidity is a fundamental aspect of market development. Our results indicated that level of illiquidity (measured by PP) in Croatia is very unstable. Since the Croatian market belongs to frontier markets, it should be transformed to emerging markets in order to become a developed market. One of the major requirements for 
this to happen is to improve market liquidity. Additionally, we showed that the Croatian market is less illiquid than the Serbian market according to the values of the ZR measure.

Future research should examine the impact of liquidity in explaining price formation in the Croatian market. I wish to investigate whether investors are compensated for holding Croatian' assets whose returns are sensitive to low level of liquidity.

\section{Acknowledgement}

This paper is a part of research projects numbers 47009 (European integrations and social and economic changes in Serbian economy on the way to the EU), and 179015 (Challenges and prospects of structural changes in Serbia: Strategic directions for economic development and harmonization with EU requirements), financed by the Ministry of Science and Technological Development of the Republic of Serbia. The author thanks Gordana Miškulin, and Mladen Tepuš for the data. All remaining errors are the author's responsibility.

\section{References}

Acharya, Viral V., and Lasse H. Pedersen. 2005. Asset Pricing with Liquidity Risk. Journal of Financial Economics, 77 (2): 375-410.

Amihud, Yakov. 2002. Illiquidity and Stock Returns: Cross Section and Time Series E?ects, Journal of Financial Markets, 5 (1): 31-56.

Amihud, Yakov, Haim Mendelson, and Lasse H. Pedersen. 2005. Liquidity and Asset Prices. Foundations and Trends in Finance, 1(4): 269-364.

Bekaert, Geert, and Campbell R. Harvey. 2002. Research in emerging markets finance: looking to the future. Emerging Markets Review, 3 (4): 429448.

Bekaert, Geert, and Campbell R. Harvey. 2003. Emerging markets finance. Journal of Empirical Finance, 10 (1-2): 3-56.

Bekaert, Geert, Campbell R. Harvey, and Christian Lundblad. 2007. Liquidity and Expected Returns: Lessons from Emerging Markets. The Review of Financial Studies, 20 (6): 1783 - 1831.

Jelena Z. Minovic - LIQUIDITY OF THE CROATIAN STOCK MARKET:

AN EMPIRICAL ANALYSIS 
Benić, Vladimir, and Ivna Franić. 2008. Stock Market Liquidity: Comparative Analysis of Croatian and Regional Markets. Financial Theory and Practice, 32 (4): 477-498.

Cajueiro, Daniel O., and Benjamin M. Tabak. 2004. The Hurst exponent over time: testing the assertion that emerging markets are becoming more effcient. Physica A, 336: 521 - 537.

Campbell, John Y., Andrew W. Lo, and A. Craig MacKinlay. 1997. The Econometrics of Financial Markets. Princeton, NJ: Princeton University Press.

Chordia Tarun, Richard Roll, and Avanidhar Subrahmanyam. 2000. Commonality in Liquidity. Journal of Financial Economics, 56: 3-28.

Chordia Tarun, Richard Roll, and Avanidhar Subrahmanyam. 2001. Market liquidity and trading activity. Journal of Finance, 56 (2): 501-530.

Chuhan, Punam. 1994. Are Institutional Investors an Important Source of Portfolio Investment in Emerging Markets?. Washington, DC: The World Bank Press, International Economics Department.

Clark, Andrew. 2008. Liquidity Risk in Frontier Markets - History, Measurement and a new approach. Thomson Reuters. http://thomsonreuters.com/content/ financial/pdf/i_and_a/liquidity_risk.pdf (accessed May 20, 2010).

Crockett, Andrew. 2008. Market liquidity and financial stability. Banque de France, Financial Stability Review - Special issue on liquidity, 11: 13-18.

Fernandez, Frank A. 1999. Liquidity risk: new approaches to measurement and Monitoring. Securities Industry Association, Working Paper

. http://archives2.sifma.org/research/pdf/workingpaper.pdf (accessed May 20, 2010).

Hacibedel, Burcu. 2007. Index Changes in Emerging Markets.

http://www.riksbank.eu/upload/Dokument_riksbank/Kat_foa

/2007/march_hacibedel.pdf (accessed May 20, 2010).

Hearn, Bruce, Jenifer Piesse, and Roger Strange. 2009. Market liquidity and stock size premia in emerging financial markets: The implications for foreign investment. International Business Review, 19 (5): 489-501.

Hasbrouck Joel, Duane J. Seppi. 2001. Common factors in prices, order 
flows and liquidity. Journal of Financial Economics, 59: 383-411.

Hibbert, John, Axel Kirchner, Gavin Kretzschmar, Ruosha Li, and Alexander McNeil. 2009. Liquidity Premium: Literature review of theoretical and empirical evidence. Research Report, http://www.barrhibb.com /documents/downloads/Liquidity_Premium_Literature_Review.PDF

Huberman Gur, and Dominica Halka. 2001. Systematic Liquidity. Journal of Financial Research, 24 (2): 161-178.

Kyle, Albert S. 1985. Continuous Auctions and Insider Trading. Econometrica, 53 (6): 1315-1335.

Latković, Mladen, and Zoran Barac. 1999. Optimizacija dionièkih portfelja na rubnim tržištim kapitala. Preprint, University of Zagreb, Zagreb, http://www.phy.hr/ laci/art/portfolio.pdf (accessed September 15, 2008).

Latković, Mladen. 2001. Nesinhrono trgovanje i proraèun sistematskog rizika. Hagena (Unpublished paper). Retrieved from http://www.phy.hr/ laci/art/beta.pdf (accessed September 15, 2008).

Lee, Kuan-Hui. 2006. Liquidity risk and asset pricing. $\mathrm{PhD}$ Thesis, The Ohio State University.

Lesmond, David A. 2005. Liquidity of emerging markets. Journal of Financial Economics, 77 (2): 411-452.

Pástor, Luboš, and Robert F. Stambaugh. 2003. Liquidity Risk and Expected Stock Returns. Journal of Political Economy, 111 (3): 642-685.

Penev, Slavica, and Matija Rojec. 2004. Foreign direct investment and the investment climate in South-East Europe. Economic Annals, 49 (163): 71-92.

Roll, Richard. 1984. A Simple Implicit Measure of the Effective Bid-Ask Spread in an Efficient Market. Journal of Finance, 39 (4): 1127-1139.

Rouwenhorst, K. Geert. 1999. Local Return Factors and Turnover in Emerging Stock Markets. Journal of Finance, 54: 1439-1464.

Wyss, Rico. 2004. Measuring and Predicting Liquidity in the Stock Market. PhD Dissertation, University St. Gallen.

Yeyati, Eduardo L., Sergio L. Schmukler, and Neeltje Van Horen. 2008. Emerging Market Liquidity and Crises. Journal of the European Economic Association, 6 (2-3): 668-682. 
Economic Research - Ekonomska Istrazivanja Vol. 25(3)

Page:801

Zhang, Huiping. 2010. Measuring Liquidity in Emerging Markets.

http://www.acem.sjtu.edu.cn/upload/publish/img/111221350130.pdf (accessed October 30, 2011).

Živković, Boško, and Jelena Minović. 2010. Illiquidity of Frontier Financial Market: Case of Serbia. Panoeconomicus, 57 (3): 349-367.

Official the Zagreb stock exchange web site: http://zse.hr/ (accessed January 20, 2010).

\section{Appendix}

TABLE A1- Descriptive Statistics for daily log prices, then for daily log returns, as well as for daily illiquidity measures of the CROBEX index, liquid and illiquid portfolio, respectively.

\begin{tabular}{lccccc}
\hline \hline & $\mathrm{E}(\mathrm{R})$ & $\mathrm{S} . \mathrm{D}$. & $\mathrm{S}$ & $\mathrm{K}$ & $\mathrm{JB}$ \\
\hline CROBEX & & & & & \\
$\mathrm{P}_{\mathrm{M}, \mathrm{t}}$ & 3.46 & 0.17 & -0.03 & 1.78 & 65.89 \\
$\mathrm{R}_{\mathrm{M}, \mathrm{t}}$ & -0.00 & 0.01 & -0.10 & 12.35 & 3841 \\
$\mathrm{PP}_{\mathrm{M}, \mathrm{t}}$ & 0.07 & 0.08 & 2.06 & 8.58 & 2116 \\
$\mathrm{TO}_{\mathrm{M}, \mathrm{t}}$ & 1398199 & 2012863 & 21.54 & 601.93 & 15865428 \\
Liquid & & & & & \\
$\mathrm{R}_{\mathrm{p}, \mathrm{t}}$ & 0.00 & 0.01 & -1.23 & 24.78 & 21120 \\
$\mathrm{PP}_{\mathrm{p}, \mathrm{t}}$ & 0.01 & 0.03 & 4.11 & 29.38 & 33580 \\
$\mathrm{TO}_{\mathrm{p}, \mathrm{t}}$ & 1523328 & 2352009 & 20.81 & 570.82 & 14262392 \\
$\mathrm{Illiquid}$ & & & & & \\
$\mathrm{R}_{\mathrm{p}, \mathrm{t}}$ & -0.00 & 0.01 & -1.60 & 17.37 & 9525 \\
$\mathrm{PP}_{\mathrm{p}, \mathrm{t}}$ & 0.82 & 0.21 & -1.27 & 4.11 & 339 \\
$\mathrm{TO}_{\mathrm{p}, \mathrm{t}}$ & 33929 & 80629 & 8.18 & 94.37 & 379124 \\
\hline \hline
\end{tabular}

Source: Author's estimation.

Notes: $P_{M, t}=\log C R O B E X ; R_{M, t}=d \log (C R O B E X) ; P P_{M, t}=P P_{-}$CROBEX; $T O_{M, t}=T O_{-} C R O B E X ; R_{p, t}$ is return of liquid or illiquid portfolio, $P P_{p, t}$ is illiquidity measure of liquid or illiquid portfolio, $\mathrm{TO}_{p, t}$ is turnover of liquid or

Jelena Z. Minovic - LIQUIDITY OF THE CROATIAN STOCK MARKET: 
illiquid portfolio. $E(R)=$ the mean value; S.D.= Standrad Deviation; $S=$ the coefficient of skewness; $K=$ the coefficient of kurtosis; JB= the Jarque-Bera test.

\section{LIKVIDNOST HRVATSKOG TRŽIŠTA DIONICA: EMPIRIJSKA ANALIZA \\ Sažetak}

Ovaj rad analizira likvidnost Hrvatskog tržišta dionica. Nizak nivo likvidnosti je jedan od ključnih problema s kojima se suočava ovo malo tržište. Kao mjere likvidnosti koristili smo nultu stopu prinosa Lesmonda, Ogdena i Trzcinke (1999), cjenovni pritisak netrgovanja kao kod Bekaerta, Harveyja i Lundblada (2007) te Promet. Za izračun nulte stope prinosa i mjera cjenovnog pritiska korištene su sve dionice prisutne na Zagrebačkoj Burzi u periodu od 2005. do 2009. Rezultati pokazuju da je nivo likvidnosti hrvatskog tržišta vrlo nizak. Na ovom je tržištu najmanje nelikvidna godina bila 200\%. (godina prije krize) a najnelikvidnija godina bila je 2009. Pokazali smo da je nelikvidnost stalno prisutna na ovom tržištu. Ponudene su prve mjere korelacije između svih mjera nelikvidnosti. Posebno se pažnja usmjerila na dokazivanje da je hrvatsko tržište manje nelikvidno od srpskog.

Ključne riječi: rubno tržište, (ne)likvidnost, Hrvatska, nulta stopa prinosa (ZR), cjenovni pritisak (PP), promet (TO).

Jelena Z. Minovic - LIQUIDITY OF THE CROATIAN STOCK MARKET: 